\title{
水中ロボットアームによる水泳時の四肢に働く非定常流体力の測定
}

\section{Measurement of Unsteady Fluid Force Acting on Limbs in Swimming Using A Robot Arm}

\author{
○高橋 明美（東工大院） 正 中島 求（東工大）
}

\begin{abstract}
Akemi TAKAHASHI, Graduate School of Tokyo Institute of Technology, 2-12-1 Ookayama, Meguro-ku, Tokyo Motomu NAKASHIMA, Tokyo Institute of Technology
\end{abstract}

Key Words: Swimming, Fluid Force, Robot Arm, SWUM

\section{1. 緒言}

著者ら ${ }^{(1)}$ は全身の剛体動力学と非定常流体力を考慮した 水泳人体シミュレーションモデル SWUM の提案を行い，そ の中でシミュレーションにおける流体力モデルの諸係数を 決定するために四肢模型を用いた非定常流体力の測定を 行っている.しかし，この模型は 1 自由度しか有していない ため泳動作を再現しているとは言い難く, 実際の水泳時に発 生する流体力についてはいまだに不明な点が多いのが現状 である。

そこで本研究では，5自由度を有し水泳時の人間の四肢に 近い運動が可能な水中ロボットアームを製作し，回流水槽中 で四肢の各部に働く非定常流体力を測定する。本論文では, 水中ロボットアームの機構および制御方法の仕様について 述べ，予備実験の結果を示す。

\section{2. 水中ロボットアーム}

2-1 機構仕様 本実験に使用する, (株)三井造船昭島研究所 社製の水中ロボットアームの機構について述べる. 図 1 にロ ボットアームの写真を示す. 本ロボットアームは上肢と下肢 の両方を表現可能であるが，ここでは上肢として説明する. 肩の屈曲/伸展, 内転/外転, 回旋と时の屈曲/伸展, および手 首の回内/回外の合計 5 自由度を有し，これらの組み合わせ によって泳動作を再現する，各関節にはひずみゲージを用い たモーメントセンサを取り付け，手首のひねりを除く 3 つの 関節の 3 軸回りのモーメントを計測する。また, 胴体部上面 に三分力計を取り付け，ロボットアーム全体に加わる荷重を 計測する.

各部の寸法は日本人標準体型をもとに決定した．上腕部お よび前腕部の寸法は，上肢の動作と下肢の動作の両方を行う ことから両者の中間となるようにしている. 手部は着脱可能 な構造とし，上肢の動作を行う際には手の模型を，下肢の動 作を行う際には足の模型を取り付ける.

2-2 計測制御システム 本システムは入力データとして各 関節の関節角 1 周期分を csv 形式で与えれば，自動的に起動 時および停止時用の運動データ作成とサンプリング周波数 に合わせた時間補間を行い, 制御用の角度指令データを作成 する. 動作時には角度指令データを DA 変換した後サーボ モータに入力する.

動作データとして各関節の角度, 荷重データとして各関節 の 3 軸まわりモーメントと三分力を計測する。これらのデー 夕を $\mathrm{AD}$ 変換した後 $\mathrm{csv}$ 形式で出力する.

\section{3. 予備実験}

3-1 実験装置 実験は(株)三井造船昭島研究所の船舶実験用 垂直循環型回流水槽を用いて行われた.

3-2 試技内容 本予備実験では, クロール, 平泳ぎ, 背泳ぎ, バタフライの 4 泳法をロボットアームによって再現した。 上 肢は上記 4 泳法全て, 下肢はクロールのバタ足と背泳ぎのバ 夕足, 平泳ぎの 3 種類を行った。

\section{4. 実験結果}

一例としてクロール上肢の実験映像を図 2 に示す. また荷 重・モーメントの計測結果として三分力計の出力結果を図 3 に示す. 周期 $8 \mathrm{~s}$, 流速 $0 \mathrm{~m} / \mathrm{s}$ の場合である. $\mathrm{x}$ 岋推進方向, $\mathrm{y}$ は横方向である.最大で約 $70 \mathrm{~N}$ の推力を発生していることが わかり，横方向についても入水時（17s 付近）に大きな流体 力が発生していることがわかる.

\section{5. 結論}

水中で泳動作に近い動作を行うロボットアームを作製し， 予備実験によって流体力の測定が可能であることを示した.

\section{引用文献}

（1）中島・佐藤 -三浦, 全身の剛体動力学と非定常流体力を 考慮した水泳人体シミュレーションモデルの開発, 機論 B, 71-705(2005), 1361-1369.

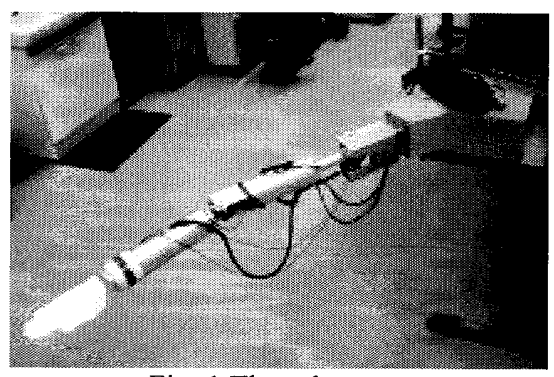

Fig. 1 The robot arm

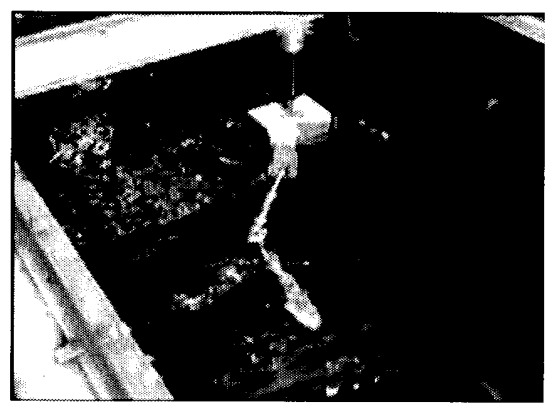

Fig. 2 Photograph of experiment (Crawl's upper arm)
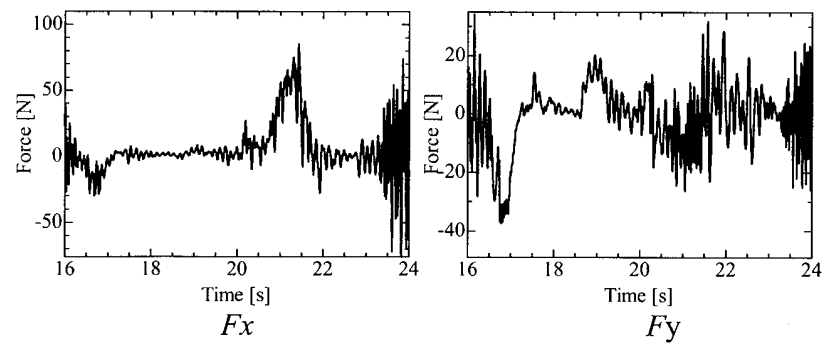

Fig.3 Force and moment of dynamometer 